\title{
THE SOVIET-BLOC FOREIGN TRADE SYSTEM
}

\author{
Nicolas SpUlber*
}

Foreign trade is a state monopoly in each of the countries of the Soviet bloc. The sphere of this monopoly encompasses not only all the export and import operations, which must be concentrated in the hands of state-chartered or designated agencies, but extends, moreover, to all the economic relations between each of these countries and the rest of the world, including their international accounts and credits. The international accounts and the other economic or noneconomic relations with other countries are handled on the basis of an organic component of the monopoly of foreign trade, the monopoly of foreign exchange.

The stated tasks of the monopoly of foreign trade are: to ward off capitalist economic penetration, to provide "maximum assistance" to domestic capital formation, and to facilitate the eventual "coordination" of the economic plans of the bloc countries. The development of foreign trade in each country is dependent on the overall economic plan: it is the latter which commands the dynamics of imports, which, in turn, determine the dynamics of exports. The government decides the volume, value, structure, and direction of its trade; thus, the monopoly offers maximum "protection" to the national economy. Tariffs, the key factor in the foreign trade of the nonbloc economies, play only a secondary role in the bloc countries.

The present article proposes to examine both the structure and the operation of the monopolies of foreign trade in the countries of the Soviet bloc, focusing in turn on: (I) organization of these monopolies; (2) their operation within and outside the bloc; (3) prices and rates of exchange; (4) extent and limitation of bloc-wide attempts toward coordination of trade and output. A final section summarizes the discussion and suggests some conclusions.

In each bloc country, the foreign trade system is headed by the ministry of foreign trade. The ministry plans all the relevant elements concerning the foreign transactions, in function of the domestic output plan, of various policy considerations, and of the existing commitments. It prepares and participates in the negotiation of foreign trade agreements, and controls and directs the organizations entering in the field of trade.

Both in the Soviet Union and in the Soviet-bloc countries, where the Soviet organi-

*A.M. 1950, Ph.D. 1952, New School for Social Research. Associate Professor of Economics and Acting Chairman, Institute of East European Studies, Indiana University. Author, The Economics or Communist Eastern Europe (1957). Co-editor, Resources and Planning in Eastern Europe (r957), East Central Europe under the Communists: Czechoslovakia (x957), The Second Soviet-Yugoslav Dispute (1959). Contributor to economic periodicals. 
zational set-up has been more or less faithfully copied, ${ }^{1}$ the ministry is organized into two types of sections or departments- "functional" and "operational." The usual functional departments are planning, foreign exchange and finance, contracts, bookkeeping and auditing, arbitration, personnel, and capital construction. The usual operational departments and/or administrations are import, export, tariffs, transport, and international forwarding. In various bloc countries, some of the functional or operational departments are split into two sections-one concerned with the relations with the bloc, the other with the nonbloc countries.

The key planning department prepares the draft-plan in close contact with the state planning commission, which transmits it to the state-chartered foreign trade corporations. The draft is constructed within the directives of the state planning commission by taking into account the basic proportions planned by it for the economy as a whole, the existing commercial commitments, the import requirements, and the foreign exchange available. The draft specifies the volume, prices and transport cost, structure, and direction of the foreign trade. The importing and exporting corporations draft, in turn, their specific plans on the basis of the physical balances (output and its allocations in physical terms) submitted to them by the producing organizations and their selling and purchasing departments. The corporations of foreign trade suggest, fit in, or complete modifications of the basic blueprint, which they present to the planning department of the ministry. The coordinated, yearly, or long-term (five-seven years) plan can then be established by the ministry and submitted for final approval to the council of ministries.

Among the other functional departments which have been mentioned above, the foreign exchange and finance department, which keeps in close contact with the state bank, concerns itself with balance-of-payments problems. The administrativeeconomic department prepares the budget of the ministry and plans and surveys the expenditure of the foreign trade organs. The contracts department studies market trends abroad, prepares the projects for interstate negotiations, and drafts instructions for the foreign trade organizations concerning the carrying out of contracts after their signature. The accounting and auditing department checks and controls the financial accounts of the ministry and its organs.

Schematically, the departments for import and export are subdivided into sections for planning and finance, and into operational sections corresponding to the basic industrial branches (metallurgy, chemicals, textile, leather, food and agricultural products, etc.). Each of the sections is, in turn, subdivided by commodities, and in

\footnotetext{
${ }^{2}$ See notably D. D. Mishustin, Sotsialisticheskaia Monopolia Vneshnei Torgovla SSSR [The Soctalist Monopoly of the Foreign Trade of the USSR] (I938); B. S. Vaganov, Voprosy Organizatsir Vneshnei Torgovli Stran Narodnol Demokratsi [Problems of the Organization of the Foreign Trade of the Countries of People's Democracy] (1954); M. F. Kovrizhnykh, A. D. Frumkin \& V. C. Pozdniakov (Eds.), Vneshniaia Torgovlia Stran Narodnot Demokratsil [Foreign Trade of the Countries of People's Democracy] (1955); D. M. Genkin (Ed.), Pravovye Voprosy VNeshnei Torgovi SSSR s Evropeiskimi Stranami Narodnor Demokratsir [Legal Problems of the Foreign Trade of the USSR with the Countries of People's Democracy] (1955); S. Shchipiorskil, Organizatsila Vneshnei Torgovli Polskol Narodnol Respubliki [Organization of the Foreign Trade of the Polish People's Republic] (1957).
} 
the case of a key commodity, also by countries. This is the case in Poland, for example, for coal, in Rumania for oil, and so on. In some countries, a special department for capital goods-distinct from the departments of imports and exports-concerns itself with the import of capital goods. In Poland, for instance, the main subsections of this department are fully-equipped plants, power equipment, machines, railroad and vehicles, ships and shipping equipment, and agricultural machinery. The other operational departments concern themselves, as their names indicate, with the policies and economies of tariffs, transport, and forwarding, and are each subdivided into sections for planning, finance, accounting, personnel, etc.

The ministry conducts its domestic activities through foreign trade commissioners and through the monopolistic corporations. The commissioners are members of the regional or republican central bodies. They supervise the facilities connected with foreign trade, propose measures for trade expansion, and survey the application of the instructions and regulations of the ministry. The monopolistic corporations are "governmental agencies operating under special status." They are state-owned organizations placed on a "commercial basis." That means that each is an independent legal entity, organized, as stated, under a separate charter which specifies its endowment by the state for the pursuit of its assigned business.2 Each organization is expected to produce planned or above-plan profits, in agreement with scheduled costs and planned profit margins, in carrying out the tasks assigned by the plan and in transacting purchases and sales at the prices established by the government. The state does not guarantee their obligations, since they are independent legal entities. The relation with the production enterprises is that of customer and supplier, regulated by special contracts. Once the over-all economic plan is approved, these contracts are concluded, within the framework of the plan, by the corporations and the selling or purchasing organizations of the economic ministries or of the trusts and "combines," specifying prices and terms of delivery.

Each of the importing, exporting, or fowarding (transport and expedition) corporations has, in turn, its functional and operational offices following the pattern indicated for the ministry of foreign trade. Basically, the importing and exporting corporations specialize according to the main industrial branches and their needs, while their offices specialize, in turn, in one type of commodity. Thus, the main importing corporations are established in each bloc country for capital goods, basic raw materials, metals and goods of mass-consumption household appliances, textiles, food, etc. The main exporting corporations are diversified according to the principal exports which the country has to offer. In the case of the Soviet Union, the export corporations handle notably grain (Eksportkhleb), coal (Soiuzugleeksport), oil (Soiuznefteksport), lumber (Eksportles), fibers (Eksportlen), as well as machines, equipment, and finished articles (Tekhnoeksport). In Czechoslovakia, for instance, the accent is on diversification in the export of fully-equipped plants (Technoexport), heavy machinery and equipment (Strojexport), precision engineering

${ }^{2}$ I V. Gsovskr, Soviet CrviL LAT 380 et seq. (1948). 
(Kovo), etc., and results in a sharper specialization in these fields. However, in Bulgaria, the corporations specializing in the sale of various agricultural produce tend to be more diversified. ${ }^{3}$ By and large, there are some twenty corporations in each of the countries of the bloc..$^{4}$ In most of these countries, a selling organization of the cooperatives is also authorized to enter the field of foreign trade, along with the state corporations.

In each country, a chamber of commerce, which is not directly included in the system of the ministry of foreign trade, assists the foreign customers in all matters connected with trade, sends delegations abroad, arranges the participation in foreigntrade fairs, obtains patents for its citizens, and so on. To it are also attached arbitration commissions.

The ministry of foreign trade carries on its operations abroad through trade delegations (in Russian, called torgovye predstavitel'stva-in short, torgpredstva). The torgpredstva, as these delegations are known in all the bloc countries, are treated as state delegations and enjoy full diplomatic immunity within the bloc, since foreign trade is considered by these countries to be a state function. The torgpredstva control the commercial activity carried on abroad by their national foreign trade corporations and insure that it conforms to the national laws of the foreign trade monopoly, grant the documents needed for the agreed commercial operations, and also study the general business trends in each country with respect to trade possibilities. In some countries, including the United States, where the torgpredstva are not accepted as state delegations, the Soviet Union and its various satellites maintain commercial agencies directly subordinated to their respective ministries of foreign trade.

\section{II}

The existence of a group of Soviet-type economies has led to the appearance of a special foreign trade market distinct from the rest of the world market-namely, the bloc or intraplanned-economies market. The interstate commercial treaties concluded between these countries are based on agreements of "friendship and mutual aid," and have both a political and commercial aim. The stated political aim is to help the signatory countries to "construct a communist society in the USSR and a socialist society in the popular democracies," while the commercial aim to to provide a well-defined framework for their commercial agreements. The commercial treaties include the provisions for most-favored-nation treatment with respect to

${ }^{3}$ Sec Nicolas Spulber, The Economics of Communist Eastern Europe i63 et seq. (1957).

- Up to 1949-50, Yugoslavia had the same organizational pattern in this field. Since then, trade has been carried out by some 500 economic agencies organized as joint-stock companies by the state-owned producing enterprises. The Government controls trade via the fixation of quotas, prohibition of exporting or importing given goods, issue of licenses, and so on. Foreign currencies are sold through the Central Foreign Currency Fund and the currency clearing houses; discriminatory rates are established according to beneficiaries and the nature of goods imported or exported. See notably Borba (Belgrade), April 20, I955; Privredni Pregled (Belgrade), Sept. Ir, I957; Devizno Poslovanje (Belgrade), Aug. $27,1958$. The whole foreign trade system is now due for overhauling. See Ekonomska Politika (Belgrade), Nov. 15, 1958 . 
physical and juridical persons of a signatory power founding themselves in the territory of the other country, export and import operations, transport of freight or passengers, and custom duties. They contain further provisions concerning arbitrage competence, exchange of specialists, organization of trade fairs, and other points of secondary importance.

Trade agreements for a determined period of one, two, or five years are signed by the governments of the bloc countries, within the general framework defined by their commercial treaties. The trade agreements state the value of the envisaged trade turnover in rubles and specify that the prices of the goods will be "fixed on the basis of world prices." An adjoining quota list indicates in quantity or value terms the broad categories of the commodities to be exchanged. The long-term trade agreements are meant to insure the basic minimum supplies needed for the outputs scheduled by the so-called "perspective" plans. The yearly agreements are meant to adjust more concretely the flows of trade to the precise needs of the yearly "operational" plan. Upon the signature of the agreement, the state banks of the two signatory countries open to each other noninterest-bearing credit accounts for the specified amount of the trade turnover. For the implementation of this trade, contracts are then negotiated and eventually concluded between the appropriate foreign trade corporations of the two countries. These contracts finally specify the quality, assortment, agreed price, date, and place of delivery of each item.

Let us now follow a whole foreign trade operation as it is carried out in practice within the bloc. On the basis of the plan, contracts are concluded between the exporting corporations and the appropriate domestic organizations selling commodities earmarked for export. The prices paid by the exporting corporations are the factory price f.o.b., not including the famous turnover tax (a sales tax with varying levels, according to the item to which it is applied). For certain scarce commodities, a special purchase authorization may also be needed. Payment to the producer is done via the so-called "acceptance" form-i.e., acceptance by the purchasing exporting corporation of the documents indicating that the goods have been sent to it by the producer. The commodity is forwarded by the exporting agency to the foreign importing agency via the appropriate channels. The settlement is made through the system of so-called "incasso with direct payment." The export organization is paid by its central bank, from the account of the buyer, upon receipt of the export documents. The bank then sends the documents to the central bank of the importing country, which, in turn, immediately credits the account of the exporter, and then presents the documents for collection of payments to the importing organization. In case of refusal of the buyer to accept the goods, the banks rapidly notify one another and adjust their accounts accordingly.

With the nonbloc countries, trade agreements are concluded in the same way, but the values involved are expressed in the currency of the nonbloc partner, in dollars

* v. F. Popov (Ed.), Gosudarstvenyt BanK SSSR 1917-1957 [The State BanK of the USSR, 19171957] 205 et seq. (1957). 
or in rubles. These are, again, bilateral agreements, with accounts carried in clearing, just as in the case of the trade within the bloc. The balance of such accounts can be covered either by gold or foreign exchange, or by the shipment of additional commodities, as is also done within the bloc. In countries with which no clearing accounts are established, the payments are made through the foreign accounts kept by the central banks with various foreign banks. Whatever the case, the trade settlements with nonbloc countries are done via the, usual letter of credit (and not through the incasso form). The exporter receives his payment from a specially agreed bank at the presentation, under specified conditions, of the export documents.

Some triangular arrangements involving one nonbloc and two bloc countries have been established on the initiative of the Soviet Union. Under one arrangement, specific Finnish exports to the Soviet Union were offset by given Polish exports to Finland, in exchange for Soviet exports to Poland. In another case, Burmese exports to the Soviet Union were offset by Czechoslovak exports to Burma, counterbalancing Soviet exports to Czechoslovakia.

Up to June 1957, the "clearing ruble" has played only the role of a bookkeeping unit of account. Since June 1957, the State Bank of the Soviet Union has started to act as a clearing house for intrabloc multilateral compensations. Given the fact that the bulk of the bloc trade continues to flow on the basis of bilateral agreements and through bilateral channels, the amount multilaterally compensable has remained, in all likelihood, rather small. This amount is built up by purchases above the minimums provided for by the bilateral agreements, purchases of various consumers' goods, and perhaps by various obligations arising from services. ${ }^{6}$ Though the planners of each country might be inclined to retain the manageable system of bilateral agreements which guarantees them the supply of a given structure and volume of imports required by their output plans, it is possible that in the future, some triangular or quadrangular arrangements would be devised, especially for raw materials, which occupy a decisive place in intrabloc trade. Thus, for instance, Soviet iron ore exports to Rumania might be offset by Rumanian oil exports to Poland, counterbalancing in part Polish coal exports to the Soviet Union. Again, such arrangements might also provide, but still in limited margins, multilaterally compensable balances. In any case, since multilateral compensation means that each bloc country would stand ready to sell goods against clearing rubles, and since the case might arise in which some countries would build net export or import surpluses with the whole bloc (over and above their regular bilateral agreements), some limits must be set to the amount of clearing rubles which each country would be supposed to accept. This kind of arrangement, similar to the one which prevailed in the defunct European Payments Union, appears even more compelling in the bloc, given the planning of both output and foreign trade and the scarcity, by

\footnotetext{
- All the bloc countries have introduced, since 1957, varying premiums on the official rate of exchange in connection with payments for services. These rates now diverge significantly from the rates prevailing in trade.
} 
definition, of exportable commodities over and above plan. A supplementary, and probably also necessary, clause might be required to provide for the conversion into gold of some of the balances built in clearing rubles.

All these various elements-the necessity of insuring planned supplies, and hence the preference for bilateral arrangements, the scarcity of exportable goods over and above plan, the necessity of limiting the amounts of freely convertible clearing rubles, and the need of providing for the conversion of the latter into gold up to a certain amount-will, along with other factors, continue to keep the multilateral compensation within narrow margins.

\section{III}

As already stated, the bloc importer or exporter pays or receives payment for the respective goods from his central bank. Payments are made in the domestic currency -rubles in Russia, zlotys in Poland, korunas in Czechoslovakia, and so on-at the prevailing rate of exchange. In each bloc country, all gold and foreign exchange is concentrated in the hands of the central bank, and all foreign accounts are carried out exclusively through that bank. Each bloc government defines the gold content of its domestic currency, so that each bloc currency can be expressed in terms of any other bloc (or nonbloc) currency. However, no foreign currency, be it of bloc or nonbloc countries, circulates within these countries, and it is strictly prohibited to take the domestic currency abroad. It is officially stated that the rate of exchange of these domestic currencies is established in a planned fashion. Actually, the rate is fixed at an arbitrary level, since neither changes in the domestic wholesale and retail prices nor changes in the world prices of the goods exported or imported by these countries affect this planned rate of exchange. ${ }^{7}$

Since domestic prices are looked upon as an element which can and must be extensively manipulated in all possible ways in order to meet various planned objectives, prices reflect only in part the underlying endowment of factors. As a rule, capital goods are furnished to the economy at various below-cost levels in order to keep the general price level down, while consumers' goods are charged with varying levels of turnover tax. Since the rate of exchange is also established at an arbitrary plateau, the planner of foreign trade is handicapped in trying to ascertain the efficiency of the foreign trade system as a whole, though he might be able to relate in a crude manner the profitability of one transaction to that of another. Each bloc country uses a different method in this field, though all these methods are qualified by their users themselves as being extremely deficient. ${ }^{8}$

\footnotetext{
${ }^{7}$ See V. V. Ikonnikov (Ed.), Denezhnoe Obrashchenie I Kredit SSSR [Monex Circulation and CREDIT IN THE USSR] 42I-22 (I954).

${ }^{8}$ To illustrate the point, let us look more closely at one of these somewhat complicated methods of computing the profitability of foreign trade. The example is based on Pavel, Pour un juste calcul de la rentabilite et de l'efficacite du commerce exterieur [For an Accurate Computation of the Profitability and Efficiency of Foreign Trade], in Erudes Economieues cahiers I06-07 (1957). In Hungary, the forcign trade enterprises use in the case of export operations a so-called "coefficient of foreign exchange," and in the case of import operations a so-called "coefficient of domestic realization." In the computation of
} 
Generally, each foreign trade organization has an established "profit norm"-i.e., a mark-up ranging from one to fifty per cent of the domestic wholesale price of the item traded. For an imported good, the mark-up is computed on the basis of the domestic wholesale price at which the good is sold to an industry. The mark-up on exported goods is calculated on the interior wholesale price, excluding the turnover tax, at which a good is usually sold by a domestic producer to a wholesale organization. If the price of the commodity sold abroad is, at the official rate of exchange, below the domestic price, including the profit of the exporting organization, the difference is covered by a subsidy from the budget. In order to obtain a particularly sought-after import, the ministry of foreign trade might enjoin the trading agencies to sell some exports at a price below cost. However, the trading agencies will generally try to sell at a profit.

Following a rule against price discrimination agreed upon in I95I, each bloc country will charge any bloc partner the same price for the same commodity, except for differences in transport cost. No assurance exists, however, of complete uniformity of prices for goods exported by more than one country in the bloc. A tendency in this direction exists through the mobility of buyers and sellers. ${ }^{9}$ As already stated, the prices at which the goods are traded in the bloc are based on "world prices." We do not know, however, whether these prices are prevailing in New York, London, or Bombay, in the same market for all commodities, or in different markets for different commodities. In establishing the price of a given commodity, the bloc partners "take into account the price of that commodity prevailing on the capitalist market in usual conditions of supply and demand."10 This presumably means that the world prices are purged of short-term fluctuations, though it is not at all clear how the bloc partners can ascertain the "usual conditions of supply and demand" in the "capitalist markets." The agreed export prices are then kept unchanged "for at least one year and for the overwhelming majority of commodities

both coefficients, the elements involved are the domestic and foreign prices paid and obtained and the official rate of exchange. Assume that the rate of exchange is I dollar for 6 forints, and I ruble for 1.5 forints. Assume further that a given commodity is purchased by the exporting enterprise at I 400 forints and sold for 200 dollars-i.e., 1200 forints at the official rate of exchange. The coefficient of foreign exchange is taken to be the ratio of the domestic price to the price obtained, computed at the official rate-i.e., $1400 \div \mathrm{I} 200=\mathrm{I} . \mathrm{I} 6$. The coefficient is then $\mathrm{I} 6 \%$ above parity. If the commodity is sold for 250 dollars, the coefficient is .93 ( $1400 \div 1500$ )-i.e., $7 \%$ below parity. The lower the coefficient, the more profitable a transaction is presumed to be. In the case of imports, if a commodity is purchased for 200 rubles and resold for 360 forints, the ruble has been "obtained" at the rate of 1.8 forints. This figure is called the "domestic rate of realization." Since at the official rate of 1.5 forints, the 200 rubles equal only 300 forints, the coefficient of domestic realization is $1.20(360 \div 300=x .20)$, or $20 \%$ above parity. If the domestic sale price is 279 , the coefficient of domestic realization is .93 , or $7 \%$ below parity. This time, the operation is presumably considered to be unprofitable. Obviously, since all the magnitudes involved-domestic price of an exported commodity, domestic price of an imported commodity, and rate of exchange-are distorted in various ways, these calculations at best allow a comparison between two foreign trade transactions of a closely related nature, but can hardly serve as an indicator of what is actually occurring in the foreign trade as a whole.

'See Spulber \& Gehrels, The Operation of Trade within the Soviet Bloc, 40 REv. Econ. \& STat. I40, I45 (1958).

${ }^{10}$ Kovrizhnykh, Frumkin, \& Pozdniakov, op. cit. supra note I, at 39. 
for a series of years."11 Hence, it is possible that at various times, the price constellation in intrabloc trade should diverge in some respects from the price constellation in the world market, even though the former constellation is patterned on the latter.

The utilization of the world price pattern creates many misgivings for Marxian economists, since according to Marx, any developed country is always in the position of exploiting a less-developed one. In Marxian terms, "an advanced country is enabled to sell its goods above their value even when it sells them cheaper than the competing countries,"12 while a less-developed country "may offer more materialized labor in goods than it receives, and yet it may receive in return commodities cheaper than it may produce them."13 Since 1948 , the theory of an implicitly unequal exchange (more materialized labor of the underdeveloped area against less labor of the highly developed country) has been heavily stressed by the Yugoslav Communists in order to suggest that unequal relations might also arise among socialist states. ${ }^{14}$ Though the Yugoslavs have been expelled from the bloc and branded as "revisionists," the question of the utilization of the world price pattern within the orbit is still high on the agenda of the bloc economists. At various bloc conferences concerning these problems, the Czechoslovak and East German economists were decidedly in favor of the further utilization of the world price pattern, while the Hungarians and Rumanians seemed to agree to this solution only with numerous reservations. Thus, the Czechslovak economist Vladmir Kaigl noted that it would not be "feasible to build a separate price-system completely severed from the existing world prices" and suggested that the gulf between the developed and the nondeveloped areas be bridged "by other means than an effort to deviate from world prices." The Rumanian economist Iosif Angel affirmed that the application of world prices to bloc trade "leads to effects harmful to the economy of industrially less developed countries."15 However, no one has indicated precisely how these harmful effects could be avoided by the manipulation of prices in foreign trade.

It is interesting to note that in I95I, the Russians were suggesting that the bloc countries were ready to set up their own intrabloc price system different in amount and ratios of the price system prevailing in the world markets. Nothing significant came out of these early claims, except the correction of world-market prices of shortrun fluctuations. Furthermore, up to now, no one has proposed the adoption of the Soviet price pattern itself in intrabloc transactions. Such an adoption would make the ruble figuring in the intrabloc transactions convertible, within the

${ }^{11}$ Id. at $39-40$.

12 3 KarL Marx, Capital 278 (Untermann transl. 1909).

${ }^{13}$ The paradox is presumed to arise from the fact that "capitals invested in foreign trade come in competition with commodities produced in other countries with lesser facilities of production." Id. at 279.

it See, e.g., Popovic, $O$ ekonomskim odnosima izmedju socijalistickih država [On the Economic Relations among the Socialist States], Komunist (Belgrade), July 1949.

${ }^{15}$ Vaněk, Rentabilita zahraničniho obchodu [Conference on the Economic Rentability of Foreign Trade], in 6 PoLıтıčka Eronomia 337 (1958); Konference o mexinárodní dëlbĕ práce v socialistické suëtové soustave [Conference on the International Division of Labor in the World Socialist System], id. at 383 . 
limits of the trade agreements, into goods at the delivery prices prevailing in the Soivet Union. But the Soviet price pattern is so distorted that presumably neither the Soviet Union nor the satellites would be able to know who would benefit, and in what amount, from any foreign trade transaction. ${ }^{16}$

\section{IV}

In order to provide for economic cooperation and coordination at the level of both trade and output planning within the bloc, a Council for Economic Mutual Assistance (CEMA) was formed in January 1949 by the Soviet Union and the EastCentral European countries: East Germany, Poland, Czechoslovakia, Hungary, Rumania, Bulgaria, and Albania. Neither Communist China nor the Asian satellites (Outer Mongolia, North Korea, and North Vietnam) are members of CEMA. Communist China, however, sends an observer to its deliberations.

CEMA has advisory and consultative functions. It makes recommendations, but lacks executive authority to enforce them. It has no fixed headquarters and meets roughly once a year in the capital of a different member country. At its sessions, CEMA examines the recommendations of its expert commissions, now some thirty-odd in number and of a permanent character since $x 956$, each of which has now its headquarters in the country best suited for its specific work. Thus, the Soviet Union is host to CEMA's heavy metallurgy commission, Czechoslovakia to the machinery-construction commission, East Germany to the chemical commission, Poland to the coal commission, Rumania to the oil and natural gas commission, Bulgaria to the agricultural commission, etc. In each commission sit permanent representatives of the ministries and planning authorities concerned in the member countries.

During the first years of CEMA's activity, which coincided with the first plans of development of the East-Central European countries-i.e., from I949 to I953-the essential method of coordination used in the bloc was the establishment of longterm trade agreements designed to guarantee the minimum supplies of basic materials needed for the carrying out of the independently-drawn national output plans. Most of these long-term trade agreements were concluded between I950 and I952, and CEMA was more or less instrumental in their preparation. During the same period, technical and scientific cooperation started to develop in the bloc through interchange of technical documentation, technical consultation, exchange of experts, training of technicians and workmen, and the like.

After the death of Stalin, the question of developing the "socialist division of

${ }^{10}$ According to a Rumanian account of the conference mentioned in note 15 supra, the Soviet delegate G. M. Sorokin, of the Moscow Economic Institute, after having noticed that the "international prices do not express world values" (?) since they are "infuenced by the monopolies," added that "the problem of the formation of prices on the socialist world market is not yet clarified theoretically." Angel, Dezbatere stiintifică pe tema diviziunii internationale a muncii in cadrul sistemului Socialist mondial [Scientific Debate on the Qttestion of the International Division of Labor in the Framework of the World Socialist System], in I I Probleme Economice I3I (1958). We can readily agree with Mr. Sorokin on this point. 
labor" received increased attention from numerous bloc quarters. During the short period of the so-called "new course" (1953-55), economic coordination was envisaged not only at the level of trade as during the preceding period, but also at the level of output. Thus, the activities of CEMA were to increase in depth and facilitate as much as possible the dovetailing of the second long-term development plans of the East European countries, scheduled to start in January 1956, at the same time as the Sixth Five-Year Plan of the Soviet Union. While these plans were still in the initial stage of implementation, the upheavals in Hungary and in Poland in the fall of that same year threw them out of gear and forced substantial changes in the basic design. The Soviet Union itself stopped short of the completion of its Sixth Five-Year Plan and shifted to a new Seven-Year-Plan for the period 1959-65. The objectives of CEMA were then proclaimed to be not only to help in the coordination of the new output plans for $196 \mathrm{I}-65$, the third long-term plan period in East Europe, but also to examine and suggest appropriate means for fitting together the plans for raw materials, fuel and power, capital construction, and transportation for the whole fifteen-year period extending from 196I to 1975 .

Within this broad framework, what has CEMA actually accomplished? While there has been much talk about the socialist division of labor, various factors have either prevented this division from occurring or have at best rendered it highly haphazard. The intrabloc division of labor has progressed little, because each of the countries of the bloc has attempted to build the same structure of production as that of the Soviet Union. Each has conceived and continues to conceive its industrialization as a process in which the national heavy (or producers' goods) industries must develop at a faster rate than the consumers' goods industries, regardless of the impact this policy may have on the standard of living. Each country has held dogmatically to the Marxian schema of "enlarged reproduction," positing that certain branches must develop faster than others, whatever the underlying endowments of factors might be. However, since 1955, it has been conceded in all these countries that each need not develop all the branches of the heavy industry, and that cooperation is necessary and possible without changing in any way the basic tenets of enlarged reproduction within each economy.

But at this point, various other key factors enter into play against any systematic division of labor. One of these factors is the impossibility of establishing some meaningful relation between the distorted interior prices and the international prices, a question which we have examined above in part three. Another factor is the inbuilt tendency of each plant, industry, sector, region, or country in the area to ensure its supplies and thus accumulate stocks or even produce spare parts or any other goods in order to break the bottlenecks which would prevent the achievement of the main economic goal-namely, the fulfillment and even overfulfillment of the output plan. Self-sufficiency becomes a virtue within a planning system whose basic emphasis is on the fulfillment of given physical-output targets. 
Another obvious factor which has operated against division of labor is the special role of the Soviet Union, given its size, economic potential, and political influence and its understandable reluctance to agree to any scheme which would imply a weakening of its control over its own output plan or a sharing of its investible resources ("accumulations") according to the bloc-wide endowments of factors. Hence, the lack of executive powers of CEMA and the necessity of achieving each specific division of labor via a bilateral or at best a triangular arrangement.

As a result of all these elements, the division of labor at the level of output ultimately presents a somewhat haphazard pattern, since it is shaped by political and technical-engineering factors, and not by cost and price considerations. It is stated now that by I960, thanks to the help of CEMA, specialization will involve ninety types of machines, twenty-seven metallurgical products, twenty-five chemical products, and so on. Each of the permanent commissions of experts examines laboriously each type of product, taking into account each plant available, and recommends a specific technical-engineering apportionment among the members. The experts propose, CEMA recommends, and the various countries involved implement, if they so decide, the recommendations made via bilateral agreements. Thus, in certain cases, given plants in a given country are earmarked to produce for the whole bloc. For example, the Zemag Works in Zeitz, East Germany, manufactures agglutination machinery (for coal briquets, sawdust, ores, etc.), the Thälman Works in Magdebourg produces large cement factories, and the Förderbrücken Gerätebau in Leuchlammer manufactures coal-stripping and removing machinery. In some cases, outputs of given specifications (e.g., trucks of five or ten tons) will be produced in this or that country, viz. Hungary and Czechoslovakia. In other cases, cooperation consists in the establishment of a joint company in which one country furnishes the raw materials, the other the industrial facilities to exploit them, viz. the HungarianRumanian company Romagchim for joint exploitation of the Rumanian natural gas.

This laborious bloc-wide technical-engineering apportionment, however, can be either obstructed or rendered of doubtful value if two important countries develop suddenly a very broad framework of bilateral cooperation. Thus, the Soviet-Czechoslovak economic relations were suddenly organized on the basis of extensive cooperation in a group of key industries following a bilateral agreement announced on January 29 , $1957 .{ }^{17}$ It is difficult to know exactly in what measure such agreements complete or cancel the bloc-wide apportionments already suggested by CEMA commissions. However, it is certain that future bloc-wide apportionments will have to be adjusted to the agreement already reached bilaterally by two of the most important members of the bloc.

The transition from the attempted coordination at the level of trade, which characterized the period up to I953, to attempted coordination at the level of output, which started from I955 onward, has had rather limited results to date. The output plans continue on parallel lines, and the planners reluctantly envisage any broad in-

${ }^{17}$ See Economies Joined by Soviet, Czechs, N.Y. Times, Jan. 30, 1957, p. 14, col. 4 . 
trabloc division of labor. If, as far as trade is concerned, each bloc country affirms that it always stands ready to buy from a bloc member rather than from a nonbloc country, even if the bloc country's prices are slightly higher and the time of delivery somewhat longer, the inbuilt autarchic tendency of each planned economy plays strongly against systematic cooperation in the current period, just as in the preceding one. The East European planner will accept willingly credits, technical assistance, or scientific cooperation, but will try to keep his domestic plan, as much as feasible, on an all-round basis and under his rigid control.

\section{V}

r. The monopoly of foreign trade has proven to be, for each Soviet-type economy, an important political-defensive and offensive tool. As far as defensive purposes are concerned, the monopoly has insured maximum protection against capitalist competition and maximum assistance to the national plan, since it has made the imports from nonbloc sources dependent on the plan needs and has tailored the exports to meet the needs of payments arising from the given imports.

2. As an instrument of political attack and offensive, the monopoly has insured the possibility, especially for the Soviet Union, of shifting rapidly from one market to another, of adjusting purchases and sales to political considerations, and of maximizing the impact of its operation, especially when the international market is in distress. In fact, the more unsettled the world market is, the more effective the monopoly appears as an instrument of commercial warfare. Furthermore, the more delicate the balance of power in the so-called noncommitted countries, the more powerful looms the capacity of the Soviet Union to adjust its trade to its political objectives. It is interesting to note that in periods of international tension, there is always talk of counteracting the Soviet monopoly of foreign trade by creating a similar foreign trade monopoly either on a national or an international scale. However, such a move is extremely difficult to fit within the framework of free-enterprise economies, and no concrete steps have thus far been taken in this direction. ${ }^{18}$

\footnotetext{
${ }^{28} \mathrm{Mr}$. James Reston recently stated that a high official of the United States Government has declared the following: "We have been discussing quietly inside our own government, for six months the need to establish an overseas trade monopoly to compete with the Soviet monopoly on equal tcrms, but this is so foreign to our normal way of doing business that we have not mentioned it in public." N.X. Times, Dec. 2, 1958, p. 17, cols. 3-5. Writing again on this problem a week later, Mr. Reston added that "men high in this Government" argue that "the United States may have to go to a radical system of state trading overseas, or even to combined state trading with the other free countries in order to counter Moscow's capacity to trade where it likes, at any prices it likes, for political advantage." Id., Dec. 7, 1958, p. E8, col. 4 .

Let me note that these are not radical new ideas-though they may become radical new policies. G. Caillaux stated in $x 93 \mathrm{I}$ in the French Senate that the only way of meeting the danger arising from the Soviet foreign trade monopoly was "to meet the adversary with his own arms." Caillaux suggested that France should decide "that nothing be sold or bought from the Soviets but through the intermediary of an Offee whose task would be to watch that there will be balance between purchases and sales. . . . The same Offee," added Caillaux, "purchasing directly for our importers, would sell them the acquired products at the prices prevailing on our market." The idea was soon taken over by Loucheur who suggested that the proposed solution be enlarged and that an International Office of Trade with the Soviet Union be formed. The Office would purchase from the Russians and "apportion the goods among the
} 
3. The pursuit of industrialization in East Europe and the organization of these economies on the Soviet model (centralized planning and monopoly of foreign trade) has encouraged, to a degree, development of intrabloc trade. Deliberate industrialization has facilitated the import of raw materials from the Soviet Union and the export toward the Soviet market of manufactured goods. Trade has further increased, thanks to the deliberate choice made by the various trading agencies involved, in favor of the intrabloc market instead of the extrabloc markets. But on the other hand, the attempt to develop each economy on an all-round basis and the manipulation by each of their own domestic prices has rendered the attempts toward a broad division of labor more implausible. The division of labor has been a hit-and-miss proposition in which, as stated, technology and engineering are supposed to provide answers which distorted costs and prices cannot give.

4. Given conclusion three above, can we conclude that "the less the degree of dependence of a national economy in its ordinary operations on trade with other countries, the less, caeteris paribus, will be the difficulties of setting up and operating a comprehensive national economic plan"? ${ }^{19}$ This assertion is certainly true in general. It is easier to set up a domestic all-round plan by reducing foreign trade to a minimum. But on the other hand, Soviet-type planning, with its deliberate priorities and branch emphasis, creates enormous imbalances in the economy. These imbalances create, in turn, a serious need for trade. Certain imports are rapidly needed in order to break various bottlenecks, and exports are needed as an outlet for certain surpluses (even such surpluses as obsolete military equipment). Thus, the intrabloc market can and does play the role of a cushion for the imbalances of the plan of the most important economy of the bloc, that of the Soviet Union.

5. The Soviet-bloc economies indicate that the intrabloc trade is "a new type of trade" in which the partners enjoy "full equality," in contrast with the relations prevailing in the capitalist world markets. The facts adduced to prove these assertions are either of a very limited import or are completely irrelevant. It is stated, for instance, that (a) equality arises because the clearing operations are carried simultaneously by the appropriate organisms of both partners, and not only by one of the two partners; (b) equality is insured by the fact that "the law of value does not operate anarchically," but that it is kept under control, and prices are established on the basis of "mutual interest and voluntary understanding."20 Evidently, the fact that both partners keep the record of their operations is rather a simple procedure of double-checking than a sign of equality. As far as prices are concerned, the fact that they are kept stable or not is irrelevant to the question of

participating countries following a given scale based on their needs." A. Stoupinitzky, Statut INTERNational de L'URSS Etat commerçant [INternational Statute of the USSR, Commercial State] r6r-62 (r936).

${ }^{10}$ JACOB VINER, The Influence of National Economic Planning on Commercial Policy, in INTERnationaL Trade and Economic Developient 85 (I952).

${ }^{20}$ Ikonnikov, op. cit. supra note 7 , at 427 et seq.; see also Kovruzhynykh, Frumkin, \& Pozdniakov, op. cit. supra note I, at 37 et seq. 
equality and mutual interest. Actually, the procedure of omitting prices in the basic trade agreements and of leaving them to be decided afterwards in the contracts concluded by the export and import agencies often places the weaker country at the complete mercy of the stronger partner. It is characteristic that in the trade with nonbloc countries, the question of the prices set by the Soviet agencies has always been one of the sore points of the trade with the Soviet Union. These prices have quite often proven higher than the international prices for goods of lower quality, with the result that many countries have had serious difficulties in implementing the trade agreement. 